\title{
Paradigma Baru Pelayanan Kesehatan : Partnership (Kemitraan) Pemerintah Bersama Masyarakat dan Swasta dalam Pelayanan Kesehatan Ibu dan Anak**
}

Oleh : M. Rizki Pratama*

*Alumnus Prodi Ilmu Administrasi Negara FISIP UNAIR

**Paper ini telah dikirimkan dalam lomba blog FPKR (Forum Peduli Kesehatan

Rakyat) dengan tema "Wajah Sistem dan Regulasi Kesehatan di Indonesia" pada tahun 2013

Pemerintah selama ini sudah sangat sering mengecewakan rakyatnya, bahkan dalam hal kewajiban yang seharusnya dilakukan oleh pemerintah untuk memenuhi kebutuhan masyarakatpun hingga hari ini belum mendapatkan perhatian yang intens. Memenuhi kebutuhan masyarakat hanya dapat dilakukan oleh pemerintah melalui pelayanan publik yang berkualitas dan kualitas pelayanan publik menentukan perkembangan peradaban masyarakat yang lebih baik lagi di masa depan. Seperti pada awal paragraf ini dalam hal pelayanan publik yang berkualitas dikatakan "jauh api dari panggang". Di hampir semua sektor pelayanan publik, terutama pelayanan kebutuhan dasar mengalami permasalahan yang sulit untuk diselesaikan tanpa adanya kemauan keras dari pemerintah sendiri. Dalam konsep negara berkembang salah satu pelayanan publik yang mendapatkan prioritas adalah pelayanan kesehatan sebab masyarakat yang dilayani dengan pelayanan kesehatan yang baik akan menjadi masyarakat yang sehat untuk melakukan kegiatan produktif, sayangnya juga pelayanan kesehatan memang masih buruk, berbagai masalah pelayanan kesehatan dapat diuraikan misalnya rendahnya anggaran untuk peningkatan pelayanan kesehatan bahkan anggaran sektor kesehatan kalah jauh dari anggaran untuk kegiatan militer yang sama sekali tidak berkontribusi secara langsung bagi masyarakat, masalah yang lain tidak meratanya sebaran tenaga medis yang rata-rata berpusat di Jawa, Sumatera dan Bali, jika sudah begini lalu bagaimana nasib saudara-saudara kita di daerah terpencil serta daerah perbatasan ? lalu ditambah lagi sarana dan prasarana yang kembali hanya berpusat di Jawa, Sumatera dan Bali meskipun tidak semuanya memiliki fasilitas yang lengkap. Padahal jelas sesuai amanat Pasal 14 UU No. 36 Tahun 2009 tentang Kesehatan, 
"Pemerintah bertanggung jawab merencanakan, mengatur, menyelenggarakan membina, dan mengawasi penyelenggaraan upaya kesehatan yang merata dan terjangkau oleh masyarakat."

Buruknya pelayanan kesehatan di Republik ini menyebabkan angka kematian ibu dan anak masih tinggi hal ini sangat berbahaya bagi kelangsungan suatu negara, sebab dengan menurunya jumlah ibu dan anak maka suksesi peradaban bangsa dapat terganggu dan warga asli dapat menjadi punah. Meskipun data terbaru dari Profil Kesehatan Kementerian Republik Indonesia menunjukkan bahwa pertama, persentase ibu hamil yang memeriksakan kehamilan ke tenaga kesehatan meningkat dari 92\% dari tahun 2002 menjadi 96\% pada tahun 2012, kedua persentase ibu yang bersalin dengan bantuan tenaga kesehatan meningkat dari 66\% pada tahun 2002 menjadi 83\% pada tahun 2012 dan ketiga persentase ibu yang bersalin di fasilitas kesehatan meningkat dari 40\% pada tahun 2002 menjadi 63\% pada tahun 2012. Dari data tersebut dapat kita baca pada dasarnya kesadaran ibu hamil akan kesehatan memang sudah meningkat dari tahun ke tahun akan tetapi jika kita melihat fakta berdasarkan survei kedokteran pada 2012, angka kematian ibu masih di atas 200 setiap 100 ribu kelahiran. Sedangkan kematian anak di atas 34 per 100 ribu kelahiran. Kemudian hasil survei Demografi dan Kesehatan Indonesia (SDKI) 2012, angka kematian ibu mencapai 359 per 100 ribu kelahiran hidup. Dalam survei yang sama, lima tahun lalu, angka kematian ibu hanya 228 per 100 ribu kelahiran hidup. Padahal seperti kita ketahun bersama bahwa target MDGs (millenium developmental goal's), yaitu angka kematian ibu maksimal 102 per 100 ribu kelahiran dan angka kematian bayi 23 per 100 ribu kelahiran. Jadi angka kematian ibu dan anak di Indonesia masih tergolong tinggi bahkan bagi saudara-saudara kita diluar pulau Jawa, Sumatera dan Bali memiliki nasib yang lebih buruk lagi sebab berdasarkan hasil sensus kesehatan 2010, daerah yang masih tinggi tingkat kematian ibu bayi berada di wilayah Indonesia timur. Untuk setiap 100 ribu kelahiran hidup di Papua, angka kematian ibu mencapai 620, Papua Barat sebanyak 573 kematian, Maluku Utara 387, dan Sulawesi Tengah 379. 
Berbagai program solutif dari pemerintah pun diluncurkan agar ibu dan anak dapat memiliki kesehatan yang prima, akan tetapi jika hanya mengandalkan pemerintah pusat saja dengan anggaran yang kecil dan terbatas maka masalah ini tidak akan pernah selesai karena cakupan wilayah Republik ini sangat luas dan membutuhkan biaya yang besar untuk dapat men-delivery program ke wilayah terpencil dan perbatasan. Peran pemerintah daerah, masyarakat, sektor swasta di daerah dan berbagai lembaga donor akhirnya menjadi setitik harapan solutif yang dapat menghapus jelaga buruknya pelayanan kesehatan. Cara-cara baru dilakukan yaitu dengan saling bekerjasama dalam kerangka partnertship (kemitraan) yang digalang bersama oleh pemerintah daerah, masyarakat dan sektor swasta. Inisiasi kemitraan dari berbagai lembaga donor baik nasional maupun internasional telah memberikan semangat baru bagi masyarakat agar ikut berpartisipasi secara aktif untuk meningkatkan pelayanan kesehatan bagi ibu dan anak di lingkungan sekitarnya.

\section{Nilai-Nilai Partnership (Kemitraan)}

Bermitra berarti memiliki posisi yang sama dalam hak dan kewajiban sehingga tidak ada bagian yang dianggap lebih tinggi atau lebih rendah. Bersepakat dalam kemitraan juga mensyaratkan kepercayaan (trust) antar pihak-pihak yang bermitra, ketika trust tidak terbangun lebih dahulu maka kemitraan tidak akan pernah terjalin, sangat logis jika pihak yang saling mencurigai satu sama lain tidak akan pernah bersahabat oleh karena itu masing-masing pihak harus melakukan tindakan-tindakan yang positif dan mendukung agar trust dapat terbangun. Kemitraan juga saling menguntungkan dalam hubungan kerja yang sinergis yang hasilnya bukanlah suatu zero-sum game, tetapi positive-sum game atau win-win solution. ${ }^{1}$ Melalui kemitraan juga akan terjadi dampak yang lebih baik daripada bekerja sendirian; all organizations share responsibility for the outcomes, and expectations may include a synergistic effect or greater gain than could be achieved through individual

\footnotetext{
${ }^{1}$ Ginadjar Kartasasmita. 1996, Pembangunan Untuk Rakyat : Memadukan Pertumbuhan Dan Pemerataan. Jakarta : CIDES, hal. 188
} 
action. ${ }^{2}$ Selain itu dengan menjalin kemitraan terdapat berbagai hal positif yang dapat diperika dari banyak pihak terkait misalnya pendapat dari Bovaird dan Loffler $^{3}$; 1) Increased interaction and exchange leads to the development of trust and the creation of norms and sanctions which reduce transaction costs; 2) It can improve access to resources among network members; 3) It can create identity resources which build a sense of 'belonging' and shared action; 4) It can have positive ripple effects within society by encouraging participation and creating greater social cohesion. Jadi melalui kemitraan setidaknya akan didapatkan meningkatkan interaksi antar pihak yang bermitra sehingga meningkatkan kepercayaan dan mengurangi biaya-biaya transaksional, meningkatkan akses sumber-sumber penting diantara para anggota, para anggota kemitraan pasti akan memiliki rasa saling memiliki dan saling bekerjasama, serta yang terakhir kemitraan dapat meningkatkan partisipasi dan kohesi sosial yang lebih baik.

\section{Paradigma Baru Pelayanan Kesehatan Ibu dan Anak}

Pelayanan publik yang dalam hal ini masuk ke dalam kategori kesehatan pada dasarnya merupakan pelayanan kebutuhan dasar masyarakat dari pemerintah yang dijamin melalui peraturan perundang-undangan, jadi sebenarnya pemerintahlah yang paling bertanggungjawab atas kualitas kesehatan masyarakatnya. Sejauh ini pemerintah memang sudah menyelenggarakan pelayanan kesehatan di hampir seluruh bagian republik ini melalui berbagai sarana misalnya posyandu, puskesmas dan rumah sakit akan tetapi masalah pelik dan beralarut-larut adalah bagaimana kualitas pelayanan kesehatan dari pemerintah ? tentu masih banyak yang harus diselesaikan seperti keterbatasan jumlah tenaga medis, Masalah tersebut tentu tidak dapat diatasi dengan mudah dan dipastikan memerlukan waktu yang lama jika begitu masyarakat dapat menjadi korban karena waktu bagi masyarakat yang sedang membutuhkan pertolongan genting dalam kesehatan adalah usaha berjuang melawan maut terutama bagi ibu dan anak yang sangat rentan akan problem kesehatan oleh karena itu harus ada tindakan solutif

\footnotetext{
${ }^{2}$ Rosemary O'Leary dan Lisa Blomgren Bingham (Ed). 2009, The Collaborative Public Manager : New Ideas For Twenty First Century, Washington D.C : Georgetown University Press, hal.6

${ }^{3}$ Tony Bovaird dan Elke Loffler. 2005, Public Management And Governance, New York : Taylor And francis, hal. 92
} 
yang mampu mengatasi permasalahan tanpa memakan waktu yang berbelit-belit dan berasal dari masyarakat sendiri sebagai stakeholder yang paling merasakan pelayanan kesehatan dari pemerintah.

Merespon dengan cepat dapat dilakukan oleh pemerintah daerah yang menjadi ujung tombak pelayanan kesehatan di daerah karena merupakan pemerintah yang paling dekat dengan masyarakat sesuai dengan tujuan otonomi daerah yaitu mendekatkan pelayanan kepada masyarakat. Jadi sudah seharusnya kemitraan lebih baik terjalin di lingkungan daerah sehingga memiliki nilai-nilai tersendiri yang dimiliki oleh masyarakat daerah tertentu.Kemitraan yang dilakukan dapat terjalin antara pemerintah daerah dengan masyarakat ataupun sektor swasta juga dimungkinkan kerjasama antara pemerintah daerah dengan berbagai organisasi non-kepemerintahan lainnya. Kemitraan sebagai model penyelesaian masalah antara pemerintah dengan masyarakat sudah dapat teruji keberhasilannya dalam memberikan dampak langsung kepada pelayanan kesehatan ibu dan anak sehingga angka kematian ibu dan anak dapat diturunkan. Sebagai paradigma baru maka banyak daerah yang mengaplikasikan konsep kemitraan sebagai solusi bersama

Model penyelesaian masalah seperti dapat dikategorikan sebagai paradigma (aliran pemikiran) baru dalam pelayanan kesehatan terutama pelayanan kesehatan ibu dan anak, sebab melalui kemitraan usaha-usaha untuk mencapai kesehatan ibu dan anak kini tidak lagi bertumpu hanya dari pemerintah saja, memang pada dasarnya pemerintahlah yang paling bertanggungjawab secara keseluruhan akan tetapi melalui kemitraan bersama dipastikan akan menghasilkan dampak yang lebih baik daripada selalu menunggu pemerintah untuk menyelesaikan masalah. Pemikiran paradigmatik amat penting dalam suatu implementasi kebijakan dalam hal ini paradigma kemitraan merupakan kerangka kerja yang mumpuni untuk meningkatkan kesadaran sekaligus kualitas kesehatan masyarakat sebab masyarakat sendiri yang secara pasti terlibat penuh untuk bekerja bersama pemerintah. Keterlibatan secara penuh seperti ini merupakan jenis partisipasi yang paling tinggi kadarnya sehingga dalam kemitraan juga akan meningkatkan kepedulian 
masyarakat pada hal-hal lain disekitarnya sehingga dapat mewujudkan masyarakat yang lebih baik.

\section{Program Kemitraan Armada Sehat Keluarga Di Kota Yogyakarta}

Program kemitraan armada sehat ini merupakan kemitraan yang terbangun melalui inisiasi dari NGO (non government organization) yang bernama Rumah Zakat. Kemudian melalui berbagai proses bersama masyarakat pemerintah daerah dan swasta lalu dimunculkanlah program kemitraan "Armada Sehat Keluarga". Program ini merupakan sebuah pelayanan komprehensif ibu dan anak menggunakan mobil keliling yang didapatkan lembaga Rumah Zakat dari CSR (corporate social responsibility) PT. Indosat Tbk, melalu mobil tersebut akhirnya Rumah Zakat berkeliling untuk menjemput bola ibu hamil dan anak untuk mendapatkan pelayanan kesehatan. Program kemitraan ini memiliki program layanan kesehatan yang ditujukan bagi ibu hamil dan balita. Pelayanan tersebut adalah Pemeriksaan Ibu Hamil, USG, Senam Hamil, Pemberian Makanan Tambahan (PMT) Ibu Hamil, Pemberian Vitamin dan Zat Besi, Kelas Ibu Hamil, Posyandu dan Tumbuh kembang Balita. Berdasarkan hasil kajian pasca program ini di implementasikan ada kenaikan derajad kesehatan ibu dan anak dengan indikatornya menurunnya angka kematian ibu dan balita. ${ }^{4}$

\section{Kemitraan Bidan Dan Dukun Bayi Di Kabupaten Trenggalek}

Program kemitraan ini melibatkan beberapa pihak yakni Dinas Kesehatan, Bidan Desa, Dukun Bayi, dan Ibu Hamil. Program ini cukup unik karena bidan desa akan bermitra dengan dukun bayi untuk menangani ibu hamil yang akan melahirkan sebab dalam lingkungan pedesaan justru dukun bayi yang dipercaya oleh masyarakat desa akan tetapi karena penanganan yang tidak higienis oleh dukun bayi maka angka kematian ibu hamil dan anak menjadi cukup tinggi di wilayah Kabupaten Trenggalek. Kemudian agar dukun bayi tidak kehilangan mata pencaharian maka setiap pasien yang diantarkan dukun bayi kepada bidan akan dihitung sebagai pembayaran dengan nominal tertentu. Program kemitraan ini

\footnotetext{
${ }^{4}$ Dwi Endah. 2012, Database Good Practice : Program Kemitraan Implementasi Armada Sehat Keluarga Kota Yogyakarta, Yogyakarta : University Network Of Governance Innovation, hal. 2
} 
menysratkan partisipasi yang tinggi dari masyarakat dan kesepakatan dari kedua belah pihak yang bermitra sebab ; Active participation is a relation based on partnership with government, in which citizens actively engage in defining the process and content of policy-making. It acknowledges equal standing for citizens in setting the agenda, proposing policy options and shaping the policy dialogue-although the responsibility for the final decision or policy formulation rests with government. Examples include, consensus conferences, citizens' juries. ${ }^{5}$ Melalui skema penelitian program kemitraan ini memberikan perubahan yang positif, yakni :1) Adanya peningkatan cakupan pertolongan persalinan oleh tenaga kesehatan dari 76,6\% pada tahun 2001 menjadi $89,7 \%$ pada tahun 2011 , 2) Adanya penurunan angka pertolongan persalinan oleh dukun dari 23,4\% pada tahun 2001 menjadi 0,7\% pada tahun 2011, 3) Adanya penurunan AKI dan AKB dari 200,13 pada tahun 2001 menjadi 103 pada tahun 2010 untuk AKI dan dari 183 pada tahun 2001 menjadi 111 pada tahun 2011 untuk AKB, 4) Jumlah dukun bayi yang melaksanakan kegiatan kemitraan bidan dan dukun bayi meningkat dari 275 orang pada tahun 2002 menjadi 368 orang pada tahun 2009. Hal ini tentu memberikan manfaat yang besar, terutama untuk ibu (hamil, bersalin, nifas) dan bayinya. ${ }^{6}$

Kemitraan bersama menjajikan perubahan yang lebih baik daripada pemerintahan yang bekerja sendirian, dukungan dari masyarakat dan berbagai pihak lain sangat dibutuhkan untuk mensukseskan gelombang paradigmatik kemitraan untuk pelayanan kesehatan ibu dan anak. Sejauh ini seharusnya kemitraan dengan pelayanan khusus ibu dan anak dapat diadopsi di sektor yang lain serta dapat direplikasi oleh berbagai komponen masyarakat, pemerintah daerah serta sektor swasta. Memang kemitraan dianggap mendegradasi kewenangan dan kekuasaan suatu pemerintah akan tetapi jika dampak yang dihasilkan oleh kemitraan ternyata mampu meningkatkan kualitas hidup masyarakat maka kemitraan bukanlah hal yang patut dihindari. Studi kasus di Kota Yogyakarta serta

\footnotetext{
5 Janet V. Denhardt dan Robert B. Denhardt. 2007, The New Public Service : Serving Not Steering, London : M.E Sharpe, hal. 97

${ }^{6}$ Dedik Sulistiawan, Nurmalasari dan Rechy Bangkit Saputra. 2012, Database Good Practice : Kemitraan Bidan Dan Dukun Bayi Di Kabupaten Trenggalek, Yogyakarta : University Network Of Governance Innovation, hal. 2
} 
Kabupaten Trenggalek telah membuktikan keberhasilan kemitraan di bidang pelayanan kesehatan ibu dan anak. Di tengah masih lesunya kemauan pemerintah pusat untuk lebih peduli pada pelayanan kesehatan yang berkualitas masih ada setitik harapan untuk meningkatkan kesehatan masyarakat melalui berbagai pihak lain yang sangat intens untuk membantu masyarakat agar lebih sehat dengan aliran pemikiran yang membebankan tanggungjawab bersama sebagai titik tumpu keberhasilan perubahan kesehatan yaitu kemitraan yang serasi, selaras dan seimbang agar ibu dan anak lebih sehat untuk menuju Indonesia sehat dan sejahtera di masa mendatang.

\section{Daftar Pustaka}

Bovaird, Tony dan Elke Loffler. 2005, Public Management And Governance, New York : Taylor And Francis.

Denhardt, Janet V. dan Robert B. Denhardt. 2007, The New Public Service : Serving Not Steering, London : M.E Sharpe.

Endah, Dwi. 2012, Database Good Practice : Program Kemitraan Implementasi Armada Sehat Keluarga Kota Yogyakarta, Yogyakarta : University Network Of Governance Innovation.

Kartasasmita, Ginadjar. 1996, Pembangunan Untuk Rakyat : Memadukan Pertumbuhan Dan Pemerataan. Jakarta : CIDES.

O'Leary, Rosemary dan Lisa Blomgren Bingham (Ed). 2009, The Collaborative Public Manager : New Ideas For Twenty First Century, Washington D.C : Georgetown University Press.

Sulistiawan, Sulistiawan, Nurmalasari dan Rechy Bangkit Saputra. 2012, Database Good Practice : Kemitraan Bidan Dan Dukun Bayi Di Kabupaten Trenggalek, Yogyakarta : University Network Of Governance Innovation. 